\title{
Modernization of physical education of student youth
}

\author{
Shuba L.V. ${ }^{1}$, Shuba V.V. ${ }^{2}$ \\ ${ }^{1}$ Zaporizhskiy National Technical University, Ukraine \\ ${ }^{2}$ Prydniprovska State Academy of Physical Culture and Sports, Ukraine
}

\begin{abstract}
Purpose:

to develop and experimentally substantiate fitness technology for students taking into account their individual peculiarities.

Material: $\quad$ The experiment was performed by girls $(n=51$, age $17-20)$ who were divided into experimental ( $n=25)$ and control $(n=26)$ groups. Classes were held twice a week during the year: 66 hours in the hall and 95 hours of independent study. At the beginning and at the end of the study, all students met the control standards, which allowed to determine the level of development of physical qualities and level of physical fitness.

Results: $\quad 8$ exercise complexes were developed to implement our fitness technology. Complexes were taken into account: interests, age, individual characteristics and level of physical fitness of students. At the first lessons the loading was about $45-50 \%$. In the future, the loading increases to $70-75 \%$ of the total time of classes.

Conclusions: When constructing fitness technology using varieties of fitness it is necessary to take into account: the type and nature of exercises, the volume and intensity of exercises, the number of repetitions and the amount of weight, the frequency of training sessions and the duration of work, intervals of rest, the number and alternation of exercises.

Keywords: technology, fitness, complexes of exercises, physical qualities, students.
\end{abstract}

\section{Introduction}

In recent years health fitness becomes very popular and aimed at achieving and maintaining an optimal physical condition and reducing the risk of cardio respiratory, immune, endocrine and other diseases $[1,3,11]$. In the system of physical education of students there is an urgent need for classes, based on the possibilities and inclination to various types of health activities. The variety of classes in many cases predetermines the interest and desire of students to do physical exercises and fitness $[4,7,32]$.

A large number of publications are devoted to the search for means to increase the efficiency of the physical education of student youth. The organizationalpedagogical and methodological basis for improving the system of physical education of students is shown in the directions: the influence of the new fitness system on the development of the level of physical fitness of youth [2, 12]; influence of physical exercises on the level of physical and functional preparedness of students with different levels of physical health [5]; peculiarities of constructing the process of physical education using exercises of a power nature $[14,36]$; modernization of the structure of education of physical qualities in student youth [42].

Researches are devoted to differentiated physical education: Ivchatova T.V. et al. and Subbota Iu.V. developed recommendations for self-study with healthimproving physical exercises, which will promote an increase in the overall tone of the body $[6,11]$; Krucevich T.Iu. - systematization of studies used to determine the level of physical development, physical fitness and functional state of children and athletes aged from 6 to 21 years old [8]; Moskalenko N.V. and Korzh N.L. - the technology of formation of value attitude of students to independent studies by physical culture [9]; Apache R. - varieties of motor activity and its influence on the development of motor qualities [13]; Savchuk S. and Kovalchuk V. - are shown the possibilities of differentiated approach to teaching students with different

(C) Shuba L.V., Shuba V.V., 2017

doi:10.15561/20755279.2017.0608 levels of physical health [43].

Other studies on the use of fitness technology were as follow:

- justified the expediency of using fitness yoga to strengthen the psychophysical state and psychosocial health of students of special medical groups in training and recreation classes on physical culture [44];

- justified and developed modified test, directed on the assessing the functional capabilities of students with disabilities in the state of health [18, 27];

- determined a substantial increase in the level of physical development and health of students through the use of modern methods of cardio-strength training [30, 34, 35];

- estimated the level of physical health and biological age of students according to their level of physical activity [19];

- estimated the state of health of schoolchildren as a subspecialty of alimentary genesis, the manifestations of which are overweight $[25,37]$.

An important component in engaging with students is the inclusion of: morpho-functional indicators [38]; the influence of modern means and methods of teaching [26, $33]$; the values of physical activity [22, 28, 29] and the duration of training [16, 23].

Studies of foreign specialists are aimed at solving various problems of raising the level of health of young people:

- raising the level of health and rehabilitation of youth $[39,40]$;

- school needs comfortable intervention programs that increase the level of student activity and knowledge about healthy behavior [21];

- presented proposals that will help teachers to structure fitness programs and pedagogical approaches (meeting needs and benefits) [31];

- the program for improving the quality of physical education can be used as a valuable foundation aimed at increasing the level of motor activity of students [45];

- the right goals and abilities / skills of the game are a 
guarantee of public health for the youth [20];

- well-designed physical education program can minimize the impact of various value orientations of teachers on the implementation of curricula and student learning [17].

From the stated positions, our topic of research is relevant and timely.

The purpose of the study is to develop and experimentally substantiate the fitness technology for students aged 17-20 years old, taking into account their individual characteristics.

\section{Material and methods.}

Participants. In the experiment participated girls $(\mathrm{n}=51$, age $-17-20$ years) who were divided into experimental $(n=25)$ and control $(n=26)$ groups. All participants have been assigned to the main medical group (no deviation in the state of health) according to a state of health.

Organization of research. The study was conducted from February 2016 to December 2016. Also, the vacation period was taken into account. In the control group, the classes were conducted according to the program, which included the development of physical qualities for the successful assimilation of motor activity techniques. During the retirement period, there have not been any proposed tasks regarding the development of physical qualities. In the experimental group, classes were conducted using developed fitness technology, taking into account the individual characteristics of students.

For the vacation period students of the experimental group offered varieties of physical exercises that would be desirable to perform during the summer holidays. These exercises were chosen in such a way as to make them as comfortable as possible for students $[6,11]$. Equipment for such classes was available regardless of location and recreation area. When constructing our fitness technology using fitness varieties were taken into account a number of important factors: the type and nature of exercises, the volume and intensity of exercises, the number of repetitions and the amount of weight, the frequency of training sessions and the duration of work, intervals of rest, the number and alternation of exercises. Also used varieties of respiratory exercises, which contributed to the restoration of the body after significant loads [3].

There were developed 8 exercise complexes for implementation our fitness technology. The following complexes were taken into account: interests, age, individual characteristics and level of physical fitness of students (Table 1).

Also in the methodology we used such methods as: uniform, repeated, interval, circular training.

A uniform method involves performing exercises continuously with relatively constant intensity, rate of work and amplitude of movements. With this method, we helped to prepare the body for the next job. The duration of continuous work was able to vary from 15 to 90 minutes and more [2]

The repeated method involves repeated exercises through intervals of rest. During the rest there was a complete restoration of the working capacity of the body of girls. The intensity of the load varied depending on the task. The intensity of the load could be $75-95 \%$ of the maximum in the chosen right. It could also be almost marginal and marginal $-95-100 \%$. The duration of the exercise was also different depending on the task $[8,42]$.

Interval method involves performing exercises (duration and intensity) through intervals of rest. In this method, the training activity has an interval of rest (with full intervals of rest between approaches: until complete recovery. Intervals varying from 3 to 5 minutes) [6].

The method of circular training provided streaming, the consistent implementation of a specially selected set of physical exercises. At the end of March and October there was an increase in the density of occupations. At the first lessons load was about $45-50 \%$. In the future, the load increases to $70-75 \%$ of the total time of employment $[2,15]$.

Each complex of exercises has always included exercises of health and preventive character. These methodical techniques contributed to the development of the motivation of girls to further work during the class. It also contributed to the discipline that ensured the safety of physical exercise.

The number of hours and duration in the control and experimental groups was the same. Classes were held twice a week: during the year, 66 hours of classes in the room and 95 hours on independent study.

At the beginning and at the end of the study, all students met the control standards, which allowed to determine the level of development of physical qualities and level of physical fitness.

Flexibility tests were used:

"tilt of the trunk forward from sitting position" $(\mathrm{cm})$ : the student sat down on the floor without shoes, the distance between the feet is $20-30 \mathrm{~cm}$. The partner is on the right and holds his knees to avoid bending them. The maximum inclination was to hold for 2-3 seconds: the fingers should be fixed on the markings. - "Deduction of straight legs in the sides" $(\mathrm{cm})$. The starting position - the student lies on the back. The student breaks straight legs to the sides. The result of the test is to measure the distance between the right and left ankle joint.

Testing of abdominal muscle strength abilities: "lifting the trunk in the sled in 1 minute" (number of times). The student lay on his back for a gymnastic mat, his knees bent at right angles, the distance between the feet $-30 \mathrm{~cm}$, fingers at the head. The partner held his feet so that the five touched the mat. The command "Can!". The student moves to sitting position. The student touches the elbows of the knees and returns to the starting position again. The result of the test was the number of ascent from a position lying in position sitting in one minute.

The development of strength abilities of muscle of hands. It was used the test "flexing and expanding the hands in the emphasis by lying" (number of times). The student bends her arms in the elbow and touches the tennis 
Table 1. Methodology of use fitness technology for girls aged 17-20 years

\begin{tabular}{|c|c|c|}
\hline Month & Method & Features of fitness technology \\
\hline $\begin{array}{l}\text { February } \\
\text { (ending) }\end{array}$ & \multicolumn{2}{|l|}{ TESTING (1) } \\
\hline March & $\begin{array}{l}\text { Uniform } \\
\text { method }\end{array}$ & $\begin{array}{l}\text { - exercises aimed at the development of general and special endurance; } \\
\text { - each lesson ended with a force block and exercises for restoration of breathing } \\
\text { and normalization of arterial pressure; } \\
\text { - work in aerobic mode, } 130-180 \text { beats / min.; } \\
\text { - complex 1, complex } 2\end{array}$ \\
\hline April & $\begin{array}{l}\text { Repeated } \\
\text { method }\end{array}$ & $\begin{array}{l}\text { - exercises of force orientation was carried out; } \\
\text { - each lesson ended with exercise on the development of flexibility using the } \\
\text { method "Stretching"; } \\
\text { - work in aerobic mode, } 130-160 \text { beats / min.; } \\
\text { - complex 3, complex } 4 \text {. }\end{array}$ \\
\hline May & $\begin{array}{l}\text { Interval } \\
\text { method }\end{array}$ & $\begin{array}{l}\text { - exercises for flexibility with different intervals; } \\
\text { - general development of physical qualities; } \\
\text { - each lesson ended with exercise using Pilates method; } \\
\text { - work in aerobic mode, } 160-180 \text { beats / min.: before the next repetition of the } \\
\text { exercise pulse } 120 \text { - } 140 \text { beats / min. (not full recovery); } \\
\text { - complex } 1 \text {, complex } 4 \text {. }\end{array}$ \\
\hline $\begin{array}{l}\text { June } \\
\text { (middle) }\end{array}$ & \multicolumn{2}{|l|}{ TESTING (2) } \\
\hline \multicolumn{3}{|c|}{ Vacation season (July - August) } \\
\hline $\begin{array}{l}\text { September } \\
\text { (beginning) }\end{array}$ & TESTING (3) & \\
\hline September & $\begin{array}{l}\text { Uniform } \\
\text { method }\end{array}$ & $\begin{array}{l}\text { - exercises aimed at the development of general and special endurance; } \\
\text { - each lesson ended with a force block and exercises for restoration of breathing } \\
\text { and normalization of arterial pressure; } \\
\text { - work in aerobic mode, } 130-180 \text { beats / min.; } \\
\text { - complex 1, complex } 3 \text {. }\end{array}$ \\
\hline October & $\begin{array}{l}\text { Circular } \\
\text { training } \\
\text { method }\end{array}$ & $\begin{array}{l}\text { - performed speed-force exercises; } \\
\text { - each lesson ended with the implementation of breathing exercises; } \\
\text { - work in aerobic mode, } 130-160 \text { beats / min.; } \\
\text { - complex 5, complex } 6 \text {. }\end{array}$ \\
\hline November & $\begin{array}{l}\text { Interval } \\
\text { method }\end{array}$ & $\begin{array}{l}\text { - performance of dance-choreographic exercises at different intervals; } \\
\text { - general development of physical qualities; } \\
\text { - each lesson ended with the implementation of relaxation exercises with musical } \\
\text { accompaniment; } \\
\text { - work in aerobic mode, } 160-180 \text { beats / min.: before the next repetition of the } \\
\text { exercise pulse } 120 \text { - } 140 \text { beats / min. (not full recovery); } \\
\text { - complex 7, complex } 8 \text {. }\end{array}$ \\
\hline December & $\begin{array}{l}\text { Repeated } \\
\text { method }\end{array}$ & $\begin{array}{l}\text { - exercises of force orientation was carried out; } \\
\text { - each lesson ended with exercise exercises on the development of flexibility } \\
\text { using the method "Stretching"; } \\
\text { - work in aerobic mode, 130-160 beats / min.; } \\
\text { - complex 1, complex } 4 .\end{array}$ \\
\hline $\begin{array}{l}\text { December } \\
\text { (ending) }\end{array}$ & TESTING (4) & \\
\hline
\end{tabular}

ball. Then the student returned to the starting position. The result of the test was the maximum number of times of touching a tennis ball in the chest.

Endurance testing. The 12-minute run was used. The result is the length of the distance, which the competitor ran for a set time with an accuracy of $1 \mathrm{~m}$.
Assessment of coordination abilities. We used the "Eight" test (Kopylov's exercise) (c). The student gets the starting position: the tilt of the trunk ahead, the ball holds in one hand. With the command "Can!” as quickly as possible, the ball makes an imaginary eight between the legs at the level of the knees (Fig. 1). At the same time 
the ball is passed from hand to hand. Result - the time of execution of ten "eight”, registered up to 0,1 s. [10, 41].

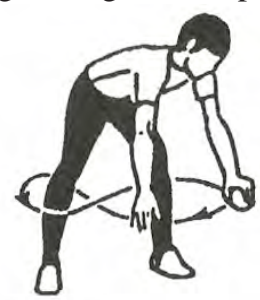

Fig. 1. Implementation of the coordination test of ten “eight” (Kopylov's exercise).

Statistical analysis. Calculations of the following values are made: average arithmetic mean, mean square deviation, coefficient of variation, standard error of mean arithmetic, correlation coefficient. The received data was processed using the Microsoft Excel program.

\section{Results}

One of the most promising areas for optimizing physical education is the rational use of effective tools, methods and technologies. This approach allows to increase the level of physical development, physical fitness of students.

Table 2 shows the results of testing the level of development of girls' physical qualities. The vacation period was also taken into account. Therefore, an intermediate test was conducted. The results of such testing showed that the figures actually decreased slightly after the holidays. This is due to the fact that for the period of holidays, students were engaged independently and chose physical exercises as they wish.

Data in table 2 show that the experiment is consistent with the indices of all tests of the group. Testing of students in early September (testing 3) indicates the need to build fitness technology.

At the end of the experiment, the results of the test "Tendency of the torso forward" increased significantly: the control group was $19 \pm 1.25(\mathrm{~cm})$; the experimental group was $23 \pm 1.18(\mathrm{~cm})(\mathrm{p}<0.05)$. After the experiment on the test "Lifting the trunk in the shed for 1 min." The following indicators were established: control group $43 \pm 1.38$ (times); experimental group - 49 $\pm 1,05$ (times) (p $<0,05)$. After experimenting with the test "Bending and extending hands in lying down", the following indicators were set: control group - $23 \pm 1.94$ (case); the experimental group was $28 \pm 1.78$ (case) $(\mathrm{p}<0.05)$. Before and after the

Table 2. Statistical values of indicators of girls' motor qualities development of aged 17-20 years during the experiment

\begin{tabular}{|c|c|c|c|c|c|c|c|c|c|}
\hline \multirow{2}{*}{ Tests } & \multirow{2}{*}{ 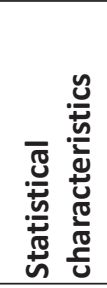 } & \multicolumn{4}{|c|}{$\begin{array}{l}\text { Girls } n-26 \\
\text { Control group } \\
\text { Testing }\end{array}$} & \multicolumn{4}{|c|}{$\begin{array}{l}\text { Girls } \mathrm{n}-25 \\
\text { Experimental group }\end{array}$} \\
\hline & & 1 & 2 & 3 & 4 & 1 & 2 & 3 & 4 \\
\hline \multirow{4}{*}{$\begin{array}{l}\text { Tendency of the torso } \\
\text { forward, }(\mathrm{cm})\end{array}$} & $\bar{x}$ & 15 & 17 & 16 & 19 & 15 & 21 & 19 & 23 \\
\hline & $\sigma$ & 1,66 & 1,52 & 1,73 & 1,46 & 1,76 & 1,78 & 1,69 & 1,56 \\
\hline & $\mathrm{V}$ & 5,11 & 4,82 & 6,12 & 5,31 & 4,66 & 4,61 & 5,89 & 4,77 \\
\hline & $\mathrm{m}$ & 1,15 & 1,10 & 1,25 & 1,16 & 1,17 & 1,09 & 1,11 & 1,18 \\
\hline \multirow{4}{*}{$\begin{array}{l}\text { Lifting the trunk in the } \\
\text { shed for } 1 \text { min. (times) }\end{array}$} & $\bar{x}$ & 37 & 39 & 40 & 43 & 38 & 45 & 46 & 49 \\
\hline & $\sigma$ & 1,31 & 1,47 & 1,51 & 1,49 & 1,43 & 1,13 & 1,22 & 1,19 \\
\hline & $\mathrm{V}$ & 6,20 & 7,01 & 7,13 & 6,55 & 6,54 & 6,91 & 7,41 & 6,32 \\
\hline & $\mathrm{m}$ & 1,23 & 0,95 & 1,49 & 1,38 & 0,67 & 1,29 & 1,19 & 1,05 \\
\hline \multirow{4}{*}{$\begin{array}{l}\text { Bending and extending } \\
\text { hands in lying down, } \\
\text { (times) }\end{array}$} & $\bar{x}$ & 19 & 21 & 20 & 23 & 19 & 24 & 22 & 28 \\
\hline & $\sigma$ & 2,01 & 1,56 & 1,97 & 1,69 & 2,84 & 2,55 & 2,07 & 2,16 \\
\hline & V & 7,28 & 7,94 & 7,77 & 6,91 & 5,25 & 6,65 & 6,81 & 6,93 \\
\hline & $\mathrm{m}$ & 2,12 & 1,70 & 2,02 & 1,94 & 1,54 & 1,69 & 2,18 & 1,78 \\
\hline \multirow{4}{*}{$\begin{array}{l}\text { Dropping straight legs to } \\
\text { the sides, }(\mathrm{cm})\end{array}$} & $\bar{x}$ & 126,84 & 134,53 & 130,12 & 136,53 & 126,11 & 138,32 & 135,09 & 140,10 \\
\hline & $\sigma$ & 7,61 & 8,39 & 8,41 & 7,91 & 6,12 & 7,62 & 7,56 & 6,88 \\
\hline & $\mathrm{V}$ & 6,48 & 8,03 & 8,44 & 7,38 & 6,54 & 5,73 & 7,04 & 6,35 \\
\hline & $\mathrm{m}$ & 5,31 & 6,83 & 7,92 & 6,33 & 5,77 & 4,97 & 6,17 & 7,03 \\
\hline \multirow{4}{*}{ 12-minute run, (m) } & $\bar{x}$ & 2651 & 2795 & 2706 & 2982 & 2654 & 2801 & 2717 & 3035 \\
\hline & $\sigma$ & 15,19 & 12,83 & 17,05 & 11,28 & 16,10 & 11,45 & 16,93 & 13,24 \\
\hline & $\mathrm{V}$ & 8,13 & 7,91 & 8,40 & 8,21 & 8,52 & 6,73 & 7,05 & 6,86 \\
\hline & $\mathrm{m}$ & 14,83 & 12,04 & 16,00 & 11,02 & 15,96 & 12,06 & 16,52 & 13,01 \\
\hline \multirow{4}{*}{ «Eight», (c) } & $\bar{x}$ & 10,80 & 9,00 & 9,72 & 8,60 & 10,70 & 8,81 & 9,04 & 7,66 \\
\hline & $\sigma$ & 0,88 & 0,57 & 0,63 & 0,45 & 0,54 & 0,48 & 0,59 & 0,72 \\
\hline & V & 8,39 & 6,81 & 7,04 & 6,77 & 8,73 & 7,11 & 7,95 & 7,02 \\
\hline & $\mathrm{m}$ & 0,71 & 0,53 & 0,55 & 0,69 & 0,46 & 0,40 & 0,39 & 0,63 \\
\hline
\end{tabular}


experiment, the high results of the test "Dropping straight legs to the sides" were established. Before the experiment: control group was $126.84 \pm 5.31(\mathrm{~cm})$; experimental group $126.11 \pm 5.77(\mathrm{~cm})$. After the experiment: control group

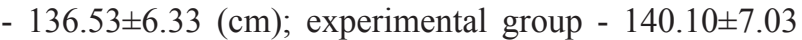
(times) $(\mathrm{p}<0.01)$. After the experiment according to the "12-minute run" was set the following parameters: control group - $2982 \pm 11.02(\mathrm{~m})$; experimental group is $3035 \pm 13.01(\mathrm{~m})(\mathrm{p}<0.05)$. After the experiment according to the test "Eighth" (Kopylov's exercises), the following parameters were established: control group - 8.60 \pm 0.69 (s); experimental group is $7.66 \pm 0.63$ (s) $(\mathrm{p}<0.01)$.

Also, it was analyzed the percentage increment of indicators of physical qualities development before and after experiment (Fig. 2). Indicators of the percentage increase indicate that the greatest increase was in the tests: "tilt of the trunk ahead"; development of flexibility; "flexing and extending the arms in the emphasis"; development of power qualities; test "eight"; development of agility.

The results of the study confirmed the effectiveness of our experimental fitness technology.

\section{Discussion}

In recent years fitness has become more popular among various types of health improvement and wellness programs. The main goal of fitness is to achieve internal harmony and external attractiveness of a man. This is the main motive for people who want to look good and feel good $[2,45]$.
Analysis of scientific literature [5, 9, 15, 31] confirmed that to date, a large variety of health-improving technologies leads to the invention of optimal fitness technology. Such technologies should take into account the age and individual characteristics of students. That confirmed our study. When constructing our fitness technology, we took into account the following: features of body building of students, physical health, set of algorithm of actions. This approach increases the efficiency of the health process. This ensures a guaranteed achievement of the result. The basis of such approach is free motivated selection of exercises. It is recommended to use innovative means, methods and organizational forms of training. It is also necessary to use modern inventory and equipment. The main goal of our fitness technology is to achieve inner harmony and external attractiveness. This is the main motive for students who want to look good and feel good.

It is important to take into account the vacation period. During the holidays, students were able to motivate and control themselves. Students were more responsive to the choice of physical exercises and their implementation. An important aspect of our study was that we conducted four tests, taking into account the vacation period. The obtained data revealed fluctuations in the test scores. This testified that not all students carefully approached independent classes. But during the final testing, the data showed high results. This gave us the opportunity to argue about the correctness of our approaches to the construction of the training process of students of the

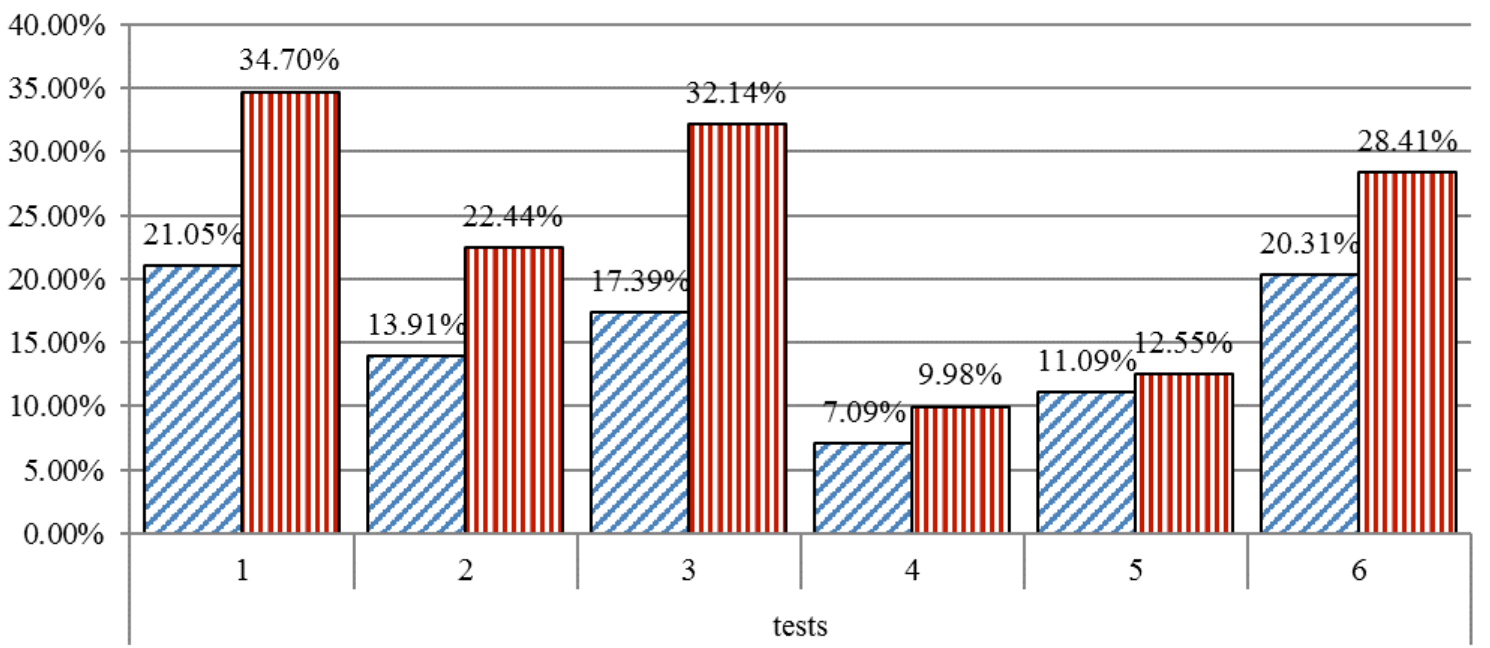

Fig.2 Growth of indicators of physical qualities development in percent among control (CG) and experimental (EG) groups.

* where:

WIII - control group,

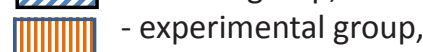

1 -test "tilt of torso forward",

2 - test "lifting the trunk in the seat in 1 minute",

3 - test "bending and extension of arms in the emphasis",

4 - test "pulling straight to the sides",

5 - test "12-minute run",

6 - test "Eight" (Kopylov's exercise). 
experimental group.

The data obtained by us confirmed the studies of other scientists $[6,11,21]$. Our data supplemented other results justifying the ratio of the proposed exercises. So, fitness technology is a process of using various physical education products with a health-improving purpose. Thus, fitness technology - is a scientific direction, which develops and improves the basis of the method of constructing physical education and recreational activities. This suggests that fitness technology is becoming more accessible and allows more general people to use them.

References

1. Bojchuk IuD. Valeological significance of physical activity. Aktual 'nye problemy fizicheskoj kul 'tury i sporta, 2011;1:360362. (in Russian)

2. Davidov VIu, Shamardin AI, Krasnova GO. . New fitness systems (new directions, techniques, equipment and tools). Volgograd: VolSU Publ.; 2005. (in Russian)

3. Dzhonson DR. Oxycise. Moscow: EKSMO; 2008. (in Russian)

4. Dovgan' N. Structural study of physical education of students of higher educational institutions. Fizichne vikhovannia, sport i kul'tura zdorov'ia u suchasnomu suspil'stvi, 2016;3(35):33 - 39. (in Ukrainian)

5. Dolzhenko LP. Physical preparedness and functional features of students with different levels of physical health. Cand. Diss. Kiev; 2007. (in Ukrainian)

6. Ivchatova TV, Soboliev IuL, Karpova IB. Self-employment exercises. Kiev: KNEU Publ.; 2007. (in Ukrainian)

7. Zaniuk SS. Psychology of motivation.Kiev: Lybid; 2002. (in Ukrainian)

8. Krucevich TIu. Methods of researching the individual health of children and adolescents in the process of physical education.Kiev: Olympic Literature; 1999. (in Russian)

9. Moskalenko NV, Korzh NL. Technology of formation of value attitude of students to independent studies by physical culture. Sportivnij visnik Pridniprov'ia, 2016;1:201 - 206. (in Ukrainian)

10.Sergiienko LP. Comprehensive testing of motor abilities of a person. Nikolaev: UDMTU; 2001. (in Ukrainian)

11. Subbota IuV. Recreational motor programs of independent exercises by physical culture and sports. Kiev: KNEU Publ.; 2007. (in Ukrainian)

12.Shuba L.V. Fitness technologies in the system of development of physical qualities of student youth. Fizichne vikhovannia, sport i kul'tura zdorov'ia u suchasnomu suspil'stvi, 2016;4(36):.45 - 52. (in Ukrainian)

13.Apache RR. Activity-based intervention in motor skill development. Percept Mot Skills. 2005;100(32):1011-20.

14.Baker JS, Cooper SM. Strength and body composition: single versus triple set resistance training programs. Medicine and Science in Sports and Exercise. 2004;36(5):14-25.

15.Bergier B, Tsos A, Bergier J. Factors determining physical activity of Ukrainian students. Annals of Environmental Medicine. 2014;21(3):613 - 616.

16. Bliznevsky AA, Kudryavtsev MD, Iermakov SS, Jagiello W. Formation of active-effective attitude of 12-13 years' judo athletes to sports functioning in competition period. Archives of Budo. 2016;12:101-15.

17.Chen A, Zhang T, Wells SL, Schweighardt R, Ennis CD. Impact of Teacher Value Orientations on Student Learning

\section{Conclusions}

The development of fitness technology took into account the initial level of physical fitness of students. Our study included independent classes: girls were engaged in selected exercises during the vacation period (July and August). The students used the exercises we offered.

The obtained data testify to the effectiveness of our fitness technology. In the experimental and control group, the greatest increase was found in the development of motor qualities: flexibility, agility and strength.

\section{Conflict of interest.}

The authors state that there is no conflict of interest.

in Physical Education. Journal of Teaching in Physical Education. 2017;36(2):152-61.

18.Drogomeretsky VV, Kopeikina EN, Kondakov VL, Iermakov SS. Adaptation of Ruffier's test for assessment of heart workability of students with health problems. Pedagogics, psychology, medical-biological problems of physical training and sports, 2017; 21(1): 4-10. doi:10.15561/18189172.2017.0101

19.Druz VA, Iermakov SS, Nosko MO, Shesterova LYe, Novitskaya NA. The problems of students' physical training individualization. Pedagogics, psychology, medicalbiological problems of physical training and sports, 2017; 21(2): 4-12. doi:10.15561/18189172.2017.0201

20.Harvey S, Song Y, Baek JH, van der Mars H. Two sides of the same coin: Student physical activity levels during a gamecentred soccer unit. European Physical Education Review. 2016;22(4):411-29.

21.Hodges MG, Hodges-Kulinna P, Kloeppel TA. Fitness for life primary: stakeholders' perceptions. Physical Education and Sport Pedagogy. 2015;20(3):299-313.

22.Iermakov SS, Arziutov GN, Jagiello W. Quick training of students to judo techniques. Archives of Budo. 2016;12:1524.

23.Iermakov SS, Podrigalo LV, Jagiello W. Hand-grip strength as an indicator for predicting the success in martial arts athletes. Archives of Budo. 2016;12:179-86.

24.Jagiello W. Differentiation of the body composition in taekwondo-ITF competitors of the men's Polish national team and direct based athletes. Archives of Budo. 2015;11:329-38.

25.Jastrzebski Z, Zychowska M, Jastrzebska M, Prusik K, Prusik K, Kortas J, et al. Changes in blood morphology and chosen biochemical parameters in ultra-marathon runners during a $100-\mathrm{km}$ run in relation to the age and speed of runners. International Journal of Occupational Medicine and Environmental Health. 2016;29(5):801-14. doi: 10.13075/ ijomeh.1896.00610

26.Khudolii OM, Ivashchenko OV, Iermakov SS, Rumba OG. Computer simulation of junior gymnasts' training process. Science of Gymnastics Journal. 2016;8(3):215-228.

27.Kopeikina EN, Drogomeretsky VV, Kondakov VL, Kovaleva MV, Iermakov SS. Modification of harvard step-test for assessment of students' with health problems functional potentials. Physical Education of Students. 2016;20(4):4450. doi:10.15561/20755279.2016.0405

28.Kozina ZL, Iermakov SS, Kuzmin VA, Kudryavtsev MD, Galimov GJ. Change of Cortisol and Insulin Content in Blood under Influence of Special Workability Recreation System for Students with High Motor Functioning Level. Research Journal of Pharmaceutical Biological and Chemical Sciences. 2016;7(2):1068-1077. 
29.Kriventsova I, Iermakov S, Bartik P, Nosko M, Cynarski WJ. Optimization of student-fencers' tactical training. Ido Movement for Culture-Journal of Martial Arts Anthropology. 2017;17(3):21-30. doi:10.14589/ido.17.3.3

30.Kudryavtsev MD, Kramida IE, Iermakov SS, Osipov AY. Development dynamic of healthy life style personality component in relatively healthy students. Physical Education of Students. 2016;20(6):26-33. doi:10.15561/20755279.2016.0603

31.Lodewyk KR, Sullivan P. Associations between anxiety, selfefficacy, and outcomes by gender and body size dissatisfaction during fitness in high school physical education. Physical Education and Sport Pedagogy. 2016;21(6):603-15.

32.Mowling CM, Brock SJ, Eiler KK. Student motivation in physical education: breaking down barrier. The Journ. of Physical Education, Recreation \& Dance. 2004;75:40 - 45.

33.Osipov AY, Kudryavtsev MD, Iermakov SS , Jagiello W. Topics of doctoral and postdoctoral dissertations devoted to judo in period 2000-2016 - the overall analysis of works of Russian experts. Arch Budo, 2017; 13: 1-10

34.Osipov AY, Kudryavtsev MD, Iermakov SS, Jagiello W. Criteria for effective sports selection in judo schools - on example of sportsmanship's progress of young judo athletes in Russian Federation. Archives of Budo. 2017;13:179-186.

35.Osipov AY, Kudryavtsev MD, Kramida IE, Iermakov SS, Kuzmin VA, Sidorov LK. Modern methodic of power cardio training in students' physical education. Physical Education of Students. 2016;20(6):34-39. doi:10.15561/20755279.2016.0604

36.Pipes TV. Strength training and fiber. Scolastic Coach, 1994;63(8):67 - 71

37.Podrigalo LV, Iermakov SS, Avdiievska OG, Rovnaya OA, Demochko HL. Special aspects of Ukrainian schoolchildren's eating behavior. Pedagogics, psychology, medical-biological problems of physical training and sports, 2017; 21(3): 120125. doi:10.15561/18189172.2017.0304

38.Podrigalo LV, Iermakov SS, Jagiełło W. Special indices of body composition as a criterion of somatic development of martial arts practitioners. Arch Budo Sci Martial Art Extreme Sport 2017; 13: 5-12

39.Radziminska A，Weber-Rajek M， Lulinska-Kuklik E, Kazmierczak U, Moska W. Academic youth's health behavior. Physical education of students, 2016; 20(6): 55-62. doi:10.15561/20755279.2016.0607

40.Radzimińska A, Weber-Rajek M, Lulińska-Kuklik E, Piecka P, Moska W. The impact of classical massage on spine mobility. Pedagogics, psychology, medical-biological problems of physical training and sports, 2017; 21(2): 82-86. doi:10.15561/18189172.2017.0206

41.Reiman MP, Manske RC. Functional Testing in Human Performance. Champaign, IL.: Human Kinetics; 2008.

42.Rink JE. Designing the physical education carriculum: promoting active life styles. Boston: McGraw-Hill Higher Education; 2009.

43.Savchuk S, Kovalchuk V. Health and structure of morbidity college students. Fizichne vikhovannia, sport $i$ kul'tura zdorov'ia u suchasnomu suspil'stvi, 2015;3(31):173 - 175.

44.Skurikhina NV, Kudryavtsev MD, Kuzmin VA, Iermakov SS. Fitness yoga as modern technology of special health groups' girl students' psycho-physical condition and psychosocial health strengthening. Physical Education of Students. 2016;20(2):24-31. doi:10.15561/20755279.2016.0204

45.Tian HL, du Toit D, Toriola AL. The effects of an enhanced quality Physical Education programme on the physical activity levels of Grade 7 learners in Potchefstroom, South Africa. Physical Education and Sport Pedagogy. 2017;22(1):35-50.

\section{Information about the authors:}

Shuba L.V.; http://orcid.org/0000-0002-8037-4218; mila.shuba@gmail.com; Zaporizhskiy National Technical University; street Zykovskogo, 64, Zaporozhye, 69063, Ukraine.

Shuba V.V.; http://orcid.org/0000-0001-5042-3106; viktoria-shuba79@yandex.ru; Prydniprovska State Academy of Physical Culture and Sports; street Embankment of Victory, 10, Dnipro, 49094, Ukraine.

Cite this article as: Shuba LV, Shuba VV. Modernization of physical education of student youth. Physical education of students, 2017;21(6):310-316. doi:10.15561/20755279.2017.0608

The electronic version of this article is the complete one and can be found online at: http://www.sportedu.org.ua/index.php/PES/issue/archive

This is an Open Access article distributed under the terms of the Creative Commons Attribution License, which permits unrestricted use, distribution, and reproduction in any medium, provided the original work is properly cited (http://creativecommons.org/licenses/by/4.0/deed.en).

Received: 16.07.2017

Accepted: 11.08.2017; Published: 08.12.2017 